\title{
China Playing Key Role in Closing African Infrastructure Gap
}

\author{
Ehizuelen Michael Mitchell Omoruyi* \\ Institute of African Studies, Zhejiang Normal University, China \\ *Corresponding author: Ehizuelen Michael Mitchell Omoruyi, Institute of African Studies, Zhejiang Normal University, China

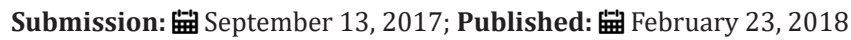

\section{Introduction}

Financial commitment in the continent has risen from $\$ 313$ million in 2000 to $\$ 4.4$ billion in 2012 Infrastructure development plays a major role in promoting growth and alleviating poverty. There are four diverse sets of economic infrastructure:

1. Irrigation for agriculture

2. Information and communications

3. Power generation

4. Transport infrastructure (road, rail, ports, airports)

These have a multiplier effect: A dollar spent on infrastructure leads to an outcome of greater than $\$ 2$. When you put a road through a backward country, you bring the country closer to development and prosperity; infrastructure is the key to wiping out poverty. In sub-Saharan Africa, however, underdeveloped infrastructure continues to be a binding constraint on sustainable development. According to Agenda 2063, building world-class infrastructure together with trade facilitation should see intra-African trade growing from less than 12 percent currently to about 50 percent by 2045 and the region share of global trade rising from 2 percent to 12 percent.

Notably, sub-Saharan Africa, through the continent's Agenda 2063, recognizes that developing infrastructure- transport, energy, water, and e-connectivity-will be critical for Africa to assume a lasting place in the global economic system. Despite years of economic growth, SSA has a serious infrastructure gap. Financing needs for infrastructure are colossal, pointing to lost growth opportunities. In 2009, the World Bank, multilateral institutions and major donors examined the challenges of sub-Saharan Africa's glaring infrastructure gap.

The investigation projected that the region required $\$ 93$ billion (77.5 billion euros; $€ 70.6$ billion) per year to fill it. In another report from the African Development Bank, inadequate water sanitation (costing the region the equivalent of 5 percent of GDP) and high transport costs (75 percent of the price of products), are identified as problems. Only half of the region's roads are paved and almost
600 million people lack access to electricity. About 30 nations have chronic power outrages. In fact, the infrastructure gap was believed to be holding back per capita economic growth by 2 percentage points annually and lessening companies' productivity by up to 40 percent.

The International Monetary Fund estimated that spending on infrastructure in sub-Saharan Africa reached about $\$ 51.4$ billion, meaning there is a financing gap of about $\$ 41.6$ billion. Reducing this gap requires improvements in the efficiency and quality of public investment in infrastructure, as well as the mobilization of public and private finance. China has become a key source to fill a substantial share of this gap. There is no doubt that China is by far the largest actor among the non-OECD (Organization for Economic Co-operation and Development) financiers, and it has made a considerable contribution toward Africa's needs, especially in the sector where the gap is largest-infrastructure.

The World Bank report, "Building Bridges: China's Growing Role as Infrastructure Financier for Sub-Saharan Africa", states that China's financial commitment in the continent has been rising appreciably from $\$ 313$ million in 2000 to $\$ 4.4$ billion in 2012. (The 2009-10 upsurge was a result of Ghana's transport commitments in 2010 (\$5.9 billion) and Ethiopian hydropower in 2009 (\$2.55 billion). The Infrastructure Consortium for Africa puts Chinese investment in African infrastructure at approximately $\$ 14.9$ billion for 2011, \$13.4 billion for 2012 and \$13.4 billion for 2013- entirely for sub-Saharan Africa. If these estimates are validated, then China is the main source of infrastructure financing in SSA outside of national budgets.

Chinese Ambassador to Ghana Sun Baohong asserted at the Dialogue Series of the College of Humanities of the University of Ghana in October 2016 that, since the Johannesburg Summit of the Forum on China-Africa Cooperation, 245 new contracts worth more than $\$ 50$ billion have been signed between China and African nations. The infrastructure financing projects include the Dares Salaam-Bagamoyo transport corridor, the Standard Gauge Railway between Nairobi and Mombasa and the Lamu Port-South Sudan- 
Ethiopia corridor. These projects will assist local economies as well as enable movement of people and merchandise.

Other key China's financing infrastructure projects include a twofold light-rail system in the Ethiopian capital; the 186-kilometer Abuja-Kaduna Railway that was completed at a cost of $\$ 850$ million in Nigeria and forms part of the larger Lagos-Kano railway construction and modernization project; the Lagos-Calabar Coastal Railway; the $\$ 1$ billion deep-sea port deal between Cameroon and China Harbour Engineering Co and the construction of the \$200 million Mammah Airport in Sierra Leone. According to the ChinaAfrica Research Initiative at the Johns Hopkins School of Advanced International Studies, most of the projects are part of the China-led Silk Road initiatives; a \$1 trillion effort envisioned to strengthen cooperation with the country's trading cohorts in the emerging nations. Also on the drawing board are a series of China-built, coalfired power plants that would reduce electrical failures and help fuel a new tax-free manufacturing zone in Djibouti. The Djibouti government hopes this project will turn into a Hong-Kong-style entre pot and international shipping center.

China is especially targeting the transport sector, particularly railways and roads. The reason for this is that these are the subsectors in which the Chinese have particular experience and where they can successfully compete for contracts under multilateral financing. Also, the Chinese feel the transport sector will transform the way Africans travel and do business with each other and the rest of the world. China's enthusiasm for infrastructure in the region stands in contrast to the role of the United States, which has largely shied away from funding infrastructure in Africa.

One of the few projects, Power Africa, a $\$ 9.7$ billion initiative announced by the former president of the United States, Barack Obama, in 2013 has fallen far short of its goal of providing electricity to more than 25 million SSA inhabitants within five years. SubSaharan African nations have grown to accept the fact that their engagement with China is about productivity, economic growth and development, and their engagement with the traditional donors is about the "soft" issues like human development, education, health and Millennium Development Goals. In this sense, the infrastructure projects, such as the Addis Ababa-Djibouti Railway and the mega-projects inaugurated on May 31, 2017-the Standard Gauge Railway (SGR), are a lifeline for East Africa and a way to achieve development and prosperity. With the Tanzania Zambia Railway Authority, or TAZARA, China has written another chapter in China-Africa cooperation.

Chinese infrastructure financing is a game-changer for subSaharan Africa's concept of the "African Moment" and "Africa Rising". According to a report in The New York Times, Daha Ahmed Osman, who works for the Djibouti government, happily said: "The Chinese shared with us their money and technology by financing our infrastructure. This will transform Djibouti and Ethiopia, and eventually all of Africa. "China infrastructure financing is turning out to have a multiplier effect, helping several African GDPs soar, along with Africans' gross domestic happiness.
Your subsequent submission with Crimson Publishers will attain the below benefits

- High-level peer review and editorial services

- Freely accessible online immediately upon publication

- Authors retain the copyright to their work

- Licensing it under a Creative Commons license

- Visibility through different online platforms

- Global attainment for your research

- Article availability in different formats (Pdf, E-pub, Full Text)

Endless customer service

- Reasonable Membership services

- Reprints availability upon request

- One step article tracking system 